\title{
Strategic application of convective cooling to maximize the thermal gradient and reduce heat stress response in dairy cows
}

\author{
D. E. Spiers, ${ }^{1}$ J. N. Spain, M. R. Ellersieck, and M. C. Lucy \\ Animal Sciences Division, University of Missouri, Columbia 65211
}

\section{ABSTRACT}

This study determined the effectiveness of convective cooling at different times of day when air temperature $\left(\mathrm{T}_{\mathrm{a}}\right)$ was cycled from day to night. Mid-lactation Holstein cows $(\mathrm{n}=12)$ were placed in 3 environmental chambers ( 4 cows per chamber) and acclimated to $\mathrm{T}_{\mathrm{a}}$ $19.9^{\circ} \mathrm{C}$ (thermoneutral; $\mathrm{TN}$ ) for $7 \mathrm{~d}$ followed by an incremental increase over $3 \mathrm{~d}$ to a heat stress (HS) condition. Conditions were maintained for $11 \mathrm{~d}$ at high and low daily $\mathrm{T}_{\mathrm{a}}$ of 33 and $23^{\circ} \mathrm{C}$, respectively. To determine adaptive HS response, the HS period was divided into early (E: d 11 to 14) and late (L: d 17 to 20) periods. During HS, cows were exposed to continuous fan (convective) cooling (CC), 8-h day fan cooling (1100 to 1900 h; DC), or 8-h night fan cooling (2300 to $0700 \mathrm{~h}$; NC). Compared with DC, the NC treatment maximized the thermal gradient during the convective cooling. Each animal received all treatments within 3 trials using a repeated $3 \times 3$ Latin square design. Cows were fed a total mixed ration and milked twice daily. Thermal status was assessed by using thermal conductance and average daily values for mean, minimum, and maximum rectal temperature $\left(\mathrm{T}_{\mathrm{re}}\right)$, skin temperatures, and respiration rate. Percent reduction in dry matter intake from $\mathrm{TN}$ to $\mathrm{HS}$ was less for $\mathrm{CC}$ than $\mathrm{DC}$ and $\mathrm{NC}$, with no change from $\mathrm{E}$ to $\mathrm{L}$ periods. The $\mathrm{DC}$ group exhibited the greatest trend for a percent reduction in total milk yield below CC due to the significantly lower morning milk production. All values for total daily milk production decreased from $\mathrm{E}$ to $\mathrm{L}$ periods, with $\mathrm{E}$ to $\mathrm{L}$ reductions in both morning and afternoon milk production. Minimum $\mathrm{T}_{\mathrm{re}}$ for $\mathrm{CC}$ and $\mathrm{NC}$ cows was $0.4^{\circ} \mathrm{C}$ below DC. In contrast, maximum $\mathrm{T}_{\mathrm{re}}$ was similar for $\mathrm{NC}$ and $\mathrm{DC}$ groups, at 0.5 to $0.6^{\circ} \mathrm{C}$ above the $\mathrm{CC}$ group. Skin temperature for $\mathrm{CC}$ cows was always less than DC cows. Skin temperature for NC cows was equal to $\mathrm{CC}$ for minimum skin temperature, but exceeded both CC and DC cows for maximum skin temperature.

Received December 13, 2017.

Accepted May 4, 2018.

${ }^{1}$ Corresponding author: spiersd@missouri.edu
Average skin temperature decreased from E to L, which suggested heat adaptation. The thermal advantage of night (lowest $\mathrm{T}_{\mathrm{a}}$ and greatest thermal gradient) versus day cooling (greatest $\mathrm{T}_{\mathrm{a}}$ and lowest thermal gradient) was increased heat transfer via thermal conductance with NC. The higher thermal strain of DC cows caused a larger percent decrease in morning milk yield than for $\mathrm{NC}$ cows. In contrast, use of convective cooling at night in the absence of elevated humidity could sufficiently reduce heat strain beyond DC to maintain milk production at a level that is closer to that of CC cows.

Key words: heat stress, thermal conductance, dairy cow

\section{INTRODUCTION}

Summer heat stress and the resultant hyperthermia are important challenges facing the dairy industry that result in an estimated annual loss of $\$ 897$ million dollars (St-Pierre et al., 2003). The traditional losses include reduced milk yield (Kadzere et al., 2002), lower reproductive rates (Wolfenson et al., 1997; Wilson et al., 1998), and depressed immune function (Elvinger et al., 1992). Core body temperature, which is the potential direct stimulus for these impaired functions, is dependent on the balance between the rates of heat gain and heat loss (Beede and Shearer, 1991). The increased heat load in the dairy cow, associated with greater milk production, has increased its thermal strain during periods of elevated ambient temperature (Kadzere et al., 2002). The housing environment and management approach must be modified, therefore, to increase heat loss and minimize thermal strain.

Modern dairy housing systems have been designed with 2 primary objectives relative to heat stress (Smith and Harner, 2012). First, the facilities should reduce exposure to external heat loads such as solar radiation. In addition, housing and milking systems have been designed to facilitate heat loss of cows with increased thermal loads associated with greater levels of milk production and concomitant increases in heat increment. Fan cooling systems have been used for many years to increase convective heat loss in these environments 
(Turner et al., 1992; Bray et al., 1994). The amount of convective heat transfer is dependent on the magnitude of the thermal gradient between exchange surfaces. One would expect, therefore, that the largest gradient for convective heat transfer exists during the night when the air temperature $\left(\mathbf{T}_{\mathrm{a}}\right)$ is typically lowest and the airto-body temperature gradient is typically the largest. Kabuga (1992) stated that nighttime release of body heat accumulated during daily exposure to heat stress is extremely important for thermal balance in lactating dairy cows. Akari et al. (1987) noted that the effect of heat stress on lactating dairy cows is ameliorated when night ambient temperatures fall. It has been suggested, in fact, that night temperature is more important than day temperature in determining the effect of summer heat on the productivity of dairy cows (Igono et al., 1992). Heat-stressed cows consume two-thirds of their total feed intake during the cooler night hours (Mallonee et al., 1985). A study of yearling beef steers demonstrated that night cooling resulted in a greater overall DMI than day cooling, and lowered mean daily respiration rate $(\mathbf{R R})$ and rectal temperature by 35 breaths per minute (bpm) and $0.5^{\circ} \mathrm{C}$, respectively (Gaughan et al., 2008).

To our knowledge, no study has evaluated the benefit of strategically cooling dairy cows when the air-to-body temperature gradient is the largest (typically at night) under controlled environment conditions. This experiment was conducted, therefore, to measure thermal balance and production responses of dairy cows exposed to strategic fan cooling when the gradient for convective heat transfer was either the greatest (nighttime cooling) or the least (daytime cooling) and to compare these responses to continuously cooled cows.

\section{MATERIALS AND METHODS}

\section{Animals}

Twelve mid-lactation Holstein cows (145 \pm 21 DIM) were moved from the Foremost Dairy Farm at the University of Missouri-Columbia to 3 environmental chambers $(6.1 \times 9.1 \mathrm{~m})$ in the Brody Environmental Center. The study was conducted in 3 trials that ran from February 10 to May 3. The selected time of year was to avoid the variance associated with introducing animals at different stages of heat acclimation or recovery. It was also at a time when there was an increase in daylight. Animals were housed in tiestalls within the chambers, with 4 animals per chamber. They were positioned approximately $1.2 \mathrm{~m}$ apart to avoid interference between animals and loosely restrained to the front of the tie stall with a chain attached to a halter. Although animals could not turn around in the stalls, they did have the ability to stand up or lie down so as not to create restraint stress. They were returned to the same chamber for each of the 3 trials used in this study. Each chamber was set to provide one experimental condition during a single trial and was then adjusted to create a new condition for each of the remaining trials. Using this approach, each chamber had each experimental condition, Animals were provided water using individual bowl waters and fed a daily diet (Table 1) for ad libitum consumption. All animal management procedures and experimental protocols were approved by the University of Missouri Animal Care and Use Committee.

\section{Experimental Design}

Twelve cows were randomly assigned to 1 of 3 fan treatments within 4 replicated $3 \times 3$ Latin square experimental designs. A total of 3 fan treatments were used in 3 trials (Figure 1). Each animal received each fan treatment during the consecutive trials. All animals

Table 1. Ingredients and chemical composition of diet fed to dairy cows

\begin{tabular}{|c|c|}
\hline Item & Amount ( $\%$ as fed) \\
\hline \multicolumn{2}{|l|}{ Feed ingredient } \\
\hline Corn silage & 32 \\
\hline Alfalfa silage & 11 \\
\hline Chopped alfalfa hay & 16.2 \\
\hline High-moisture shelled corn & 12.8 \\
\hline Soybean meal, $48 \%$ & 5 \\
\hline Soybean hulls & 6 \\
\hline Corn gluten feed & 9.6 \\
\hline Fish meal & 0.5 \\
\hline Hydrolyzed animal fat ${ }^{1}$ & 0.7 \\
\hline Ground corn & 5.1 \\
\hline Dicalcium phosphate & 0.3 \\
\hline Salt & 0.1 \\
\hline Dynamate $^{2}$ & 0.2 \\
\hline Limestone & 0.3 \\
\hline Trace minerals ${ }^{3}$ & 0.1 \\
\hline Vitamins $\mathrm{A}, \mathrm{D}$, and $\mathrm{E}^{4}$ & 0.06 \\
\hline Vitamin $\mathrm{E}^{5}$ & 0.06 \\
\hline \multicolumn{2}{|l|}{ Chemical composition $^{6}$} \\
\hline OM \% & 92.1 \\
\hline $\mathrm{CP} \%$ & 16.6 \\
\hline $\mathrm{ADF} \%$ & 24.5 \\
\hline $\mathrm{NDF} \%$ & 40 \\
\hline
\end{tabular}

${ }^{1}$ Manufactured by Southwest Byproducts (Springfield, MO).

${ }^{2}$ Trade name for mineral supplement containing guaranteed minimum analysis of $22 \%$ sulfur, $18 \%$ potassium, $11 \%$ magnesium produced by IMC Agrico (Mundelein, IL).

${ }^{3}$ Mineral mixes were formulated to contain $12 \% \mathrm{Ca}, 10 \% \mathrm{Fe}, 8 \% \mathrm{Mn}$, $8 \% \mathrm{Zn}, 2 \% \mathrm{CuSO}_{4}, 200 \mathrm{mg} / \mathrm{kg}$ of Co, $10,000 \mathrm{mg} / \mathrm{kg}$ of Se.

${ }^{4}$ Contained $88,200,000 \mathrm{IU} / \mathrm{kg}$ of vitamin A, 1,764,000 IU $/ \mathrm{kg}$ of vitamin $\mathrm{D}_{3}$, and $2,646 \mathrm{IU} / \mathrm{kg}$ of vitamin $\mathrm{E}$.

${ }^{5}$ Contained $44,100 \mathrm{IU} / \mathrm{kg}$ of vitamin E.

${ }^{6}$ Mean dietary DM content was $56.4 \pm 2.8 \%$. 


\begin{tabular}{|c|c|c|}
\hline \multicolumn{3}{|c|}{ Trial 1} \\
\hline $\begin{array}{c}\text { Chamber A } \\
\text { Cows } 1 \text { to } 4 \\
\text { Continuous fans }\end{array}$ & $\begin{array}{l}\text { Chamber B } \\
\text { Cows } 5 \text { to } 8 \\
\text { Day fans }\end{array}$ & $\begin{array}{l}\text { Chamber C } \\
\text { Cows } 9 \text { to } 12 \\
\text { Night fans }\end{array}$ \\
\hline \multicolumn{3}{|c|}{ Trial 2} \\
\hline $\begin{array}{l}\text { Chamber A } \\
\text { Cows } 1 \text { to } 4 \\
\text { Day fans }\end{array}$ & $\begin{array}{l}\text { Chamber B } \\
\text { Cows } 5 \text { to } 8 \\
\text { Night fans }\end{array}$ & $\begin{array}{c}\text { Chamber C } \\
\text { Cows } 9 \text { to } 12 \\
\text { Continuous fans }\end{array}$ \\
\hline \multicolumn{3}{|c|}{ Trial 3} \\
\hline $\begin{array}{l}\text { Chamber A } \\
\text { Cows } 1 \text { to } 4 \\
\text { Night fans }\end{array}$ & $\begin{array}{c}\text { Chamber B } \\
\text { Cows } 5 \text { to } 8 \\
\text { Continuous fans }\end{array}$ & $\begin{array}{c}\text { Chamber C } \\
\text { Cows } 9 \text { to } 12 \\
\text { Day fans }\end{array}$ \\
\hline
\end{tabular}

Figure 1. Latin square design used in the study including treatments and trials. Three fan treatments in 3 trials were used. Each animal received each fan treatment during the consecutive trials. All animals received the same treatment within an environmental chamber. Cows were returned to the university dairy farm for $24 \mathrm{~d}$ between trials.

received the same treatment within a chamber. Three chambers, therefore, each held 4 cows, so that each environmental treatment was represented in each chamber once in the replicated $3 \times 3$ Latin square (cows and trials). Cows remained in the assigned environmental chamber for the 3 treatment trials, but were returned to the Foremost Dairy Farm between trials. Animals were not exposed to heat stress conditions for $24 \mathrm{~d}$ between each trial to minimize any acclimation or carryover effects. Cows were the experimental unit and also served as the complete block.

Lights were on in each chamber from 0430 to 2330 h. Cows were milked twice daily at 0500 and $1700 \mathrm{~h}$ with practices outlined by the National Mastitis Council that represent best practices/standard procedures/ animal welfare. Milk was collected into stainless steel milk buckets and production was recorded for each cow at each milking by manually weighing the milk (AccuWeigh, MetroEquipment Corp., Sunnyvale, CA).

During the first $7 \mathrm{~d}$ of each trial, the chambers were maintained under thermoneutral (TN) conditions with a $\mathbf{T}_{\mathrm{a}}$ of approximately $19^{\circ} \mathrm{C}$ and $40 \%$ relative humidity for $24 \mathrm{~h}$ a day (Figure 2). The temperature-humidity index (THI) calculated according to Thom (1959) was 64 . Heat exposure began following the $7 \mathrm{~d}$ TN condition. Air temperature increased on d 8 from 19 to $23^{\circ} \mathrm{C}$ from 0700 to $1100 \mathrm{~h}$, and held at this $\mathrm{T}_{\mathrm{a}}$ until $1900 \mathrm{~h}$ when followed by a slight reduction to $22^{\circ} \mathrm{C}$. On d 9 , $\mathrm{T}_{\mathrm{a}}$ was increased to $29^{\circ} \mathrm{C}$ over the same time as for $\mathrm{d} 8$. Air temperature decreased to $23^{\circ} \mathrm{C}$ and then increased to $33^{\circ} \mathrm{C}$ on $\mathrm{d} 10$. Following the 3 -d step-up, a daily cycle from a night low of $23^{\circ} \mathrm{C}$ to day high of $33^{\circ} \mathrm{C}$ was maintained for the remaining $11 \mathrm{~d}$ of each trial and this is referred to as the heat stress period (HS). Relative humidity was maintained at approximately $50 \%$ during this period. Daily ambient conditions of the chambers in terms of THI during the 3 treatments are illustrated in Figure 3A, along with the average hourly change of THI, $\mathrm{T}_{a}$, and percent relative humidity through a single day (Figures 3B, 3C, and 3D, respectively). Across all 3 trials the ranges for the ambient variables during the HS period were $42.4 \pm 1.3$ to $54.6 \pm 1.1 \%$ for $\mathrm{RH}, 21.2$ \pm 0.2 to $34.5 \pm 0.2^{\circ} \mathrm{C}$ for ambient temperature, and $67.1 \pm 0.2$ to $83.7 \pm 0.2$ for THI.

During HS, cows were exposed to continuous fan cooling (continuously cooled, CC), 8-h day fan cooling (day cooled, DC; 1100 to $1900 \mathrm{~h}$ ), or 8-h night fan cooling (night cooled, NC; 2300 to 0700 h). Fan cooling was achieved using Schaeffer Barn Kooler Fans (30.48 cm diameter, model VS-12, Schaefer Ventilation Equipment, Sauk Rapids, MN). Each fan was placed $0.9 \mathrm{~m}$ in front of the cow and $2.0 \mathrm{~m}$ above the floor. Air speed was $11.5 \mathrm{~km} / \mathrm{h}$ or $3.2 \mathrm{~m} / \mathrm{s}$, and air stream was directed at a $45^{\circ}$ angle with the horizontal plane of the animal and toward the withers.

\section{Measurements}

Milk production was determined daily at AM (0500 h) and PM (1700 h) times. Cows were individually fed 


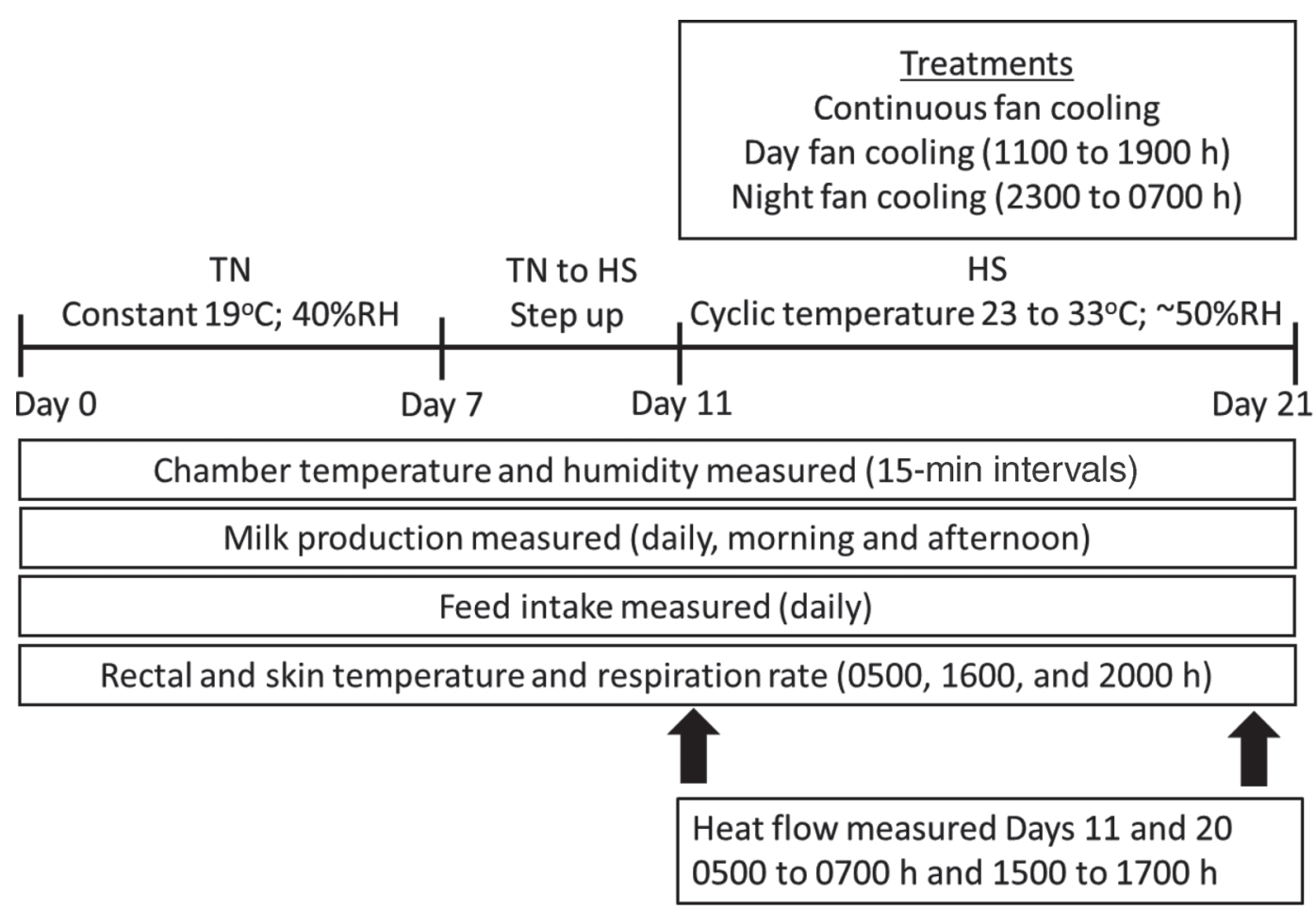

Figure 2. Experimental design and timeline for data collection. $\mathrm{TN}=$ thermoneutral; $\mathrm{HS}=$ heat stress; $\mathrm{RH}=$ relative humidity.

the same corn silage-based TMR. The diet was formulated to support $45 \mathrm{~kg}$ of milk containing $3.8 \%$ milk fat (Table 1). Fresh feed was placed in the individual feeders twice daily at 1000 and $1900 \mathrm{~h}$. Orts were removed and weighed before the morning feeding to measure the individual feed intake. Water intake was not measured, even though automated water systems were available, because some animals splashed the water out of their bowls and this produced erroneous values. Dataloggers (HOBO H8 ProSeries, Onset Computer Corporation, Bourne, MA) were used in each room to record $T_{a}$ and percent relative humidity, and these data were used to calculate THI. Thermal status metrics of each cow were manually determined at 0500, 1600, and $2000 \mathrm{~h}$ each day. Rectal temperature $\left(\mathbf{T}_{\mathbf{r e}}\right)$ was measured, using a thermistor probe (model 403, YSI Inc., Yellow Springs, $\mathrm{OH}$ ) attached to a temperature recorder (model 8110 20, Cole-Parmer Instrument Co., Vernon Hills, IL), as one indicator of thermal status. The thermistor probe was calibrated before use to $0.1^{\circ} \mathrm{C}$ using a National Bureau of Standards thermometer. Collier et al. (2006) reported that infrared skin temperature, in general, is highly correlated with $\mathrm{RR}$ and is a good measure of the microenvironment around the animal. Infrared skin temperature in the present study was determined using a calibrated, infrared thermometer (model C-1600, Linear Laboratories, Freemont, CA) at shaved sites on shoulder, rump, and the upper surface of the base of the tail regions. Maintenance shaving was performed throughout the study to keep the areas free of hair. Respiration rate was determined by visual counting of flank movement over a 1-min interval.

Heat flow at the 3 shaved skin sites was determined for each of the 12 animals in each of the 3 treatments using a calibrated heat flow disk $(6 \mathrm{~mm}$ diameter, 1 $\mathrm{mm}$ thickness; $704.8 \mathrm{~W} / \mathrm{m}^{2}$ per $\mathrm{mV}$; Concept Engineering, Old Saybrook, CT) connected to a voltage datalogger (Molytek 3702A 32-Channel Portable Recorder, The Partlow Corp., New Hartford, NY) and held gently against the shaved skin for approximately 1 min until values stabilized. Measurement times for the 3 treatment groups included afternoon (i.e., PM: prior to milking at $1500-1700 \mathrm{~h}$ ) and morning (i.e., AM: after milking at $0500-0700 \mathrm{~h}$ ) hours, and were made on d 11 and 20 of the heat exposure phase of each trial.

\section{Statistical Analysis}

Thermoregulatory and production responses of cattle to controlled heat stress can be usually characterized as acute (i.e., d 3-4) and chronic (i.e., d 7 or later; Brown-Brandl et al., 2003; Spiers et al., 2004; BrownBrandl et al., 2005). The thermoregulatory response is shown as a rapid rise in core temperature during the acute phase followed by a decline and stabilization at an intermediate level during the chronic phase. The 
production response during the acute phase initially began with the maintenance of $\mathrm{TN}$ levels of feed intake and milk production, followed by a slow decline over days to the chronic phase (Spiers et al., 2004). To identify the thermoregulatory phase differences in the present study, animal responses during the stable heat stress period were grouped into early (E; d 11-14) and late (L; d 17-20) phases. In each phase, the maximum, mean, and minimum values for $\mathrm{T}_{\mathrm{re}}, \mathrm{RR}$, and skin temperatures were first determined for each animal for each day. Daily values for AM milk production, PM milk production, total milk production, and total feed intake for each animal were averaged to provide single values for that animal that represented that phase, followed by analysis as described later to determine statistical differences. Change in production from a TN baseline (i.e., average of d 6 and 7; Figure 3) was determined for each animal in each heat stress period and analyzed as for the other variables.

The basic statistical design for the analysis of $T_{\text {re }}$, $\mathrm{RR}$, skin temperatures, and production values was 4 repeated $3 \times 3$ Latin squares all run at the same time with repeated measures. The main plot contained column (animal $=12)$, row $($ trial $=3)$, and treatment (i.e., CC, NC, DC). The subplot contained the effect of period (early, late), day, period $\times$ day, and all possible

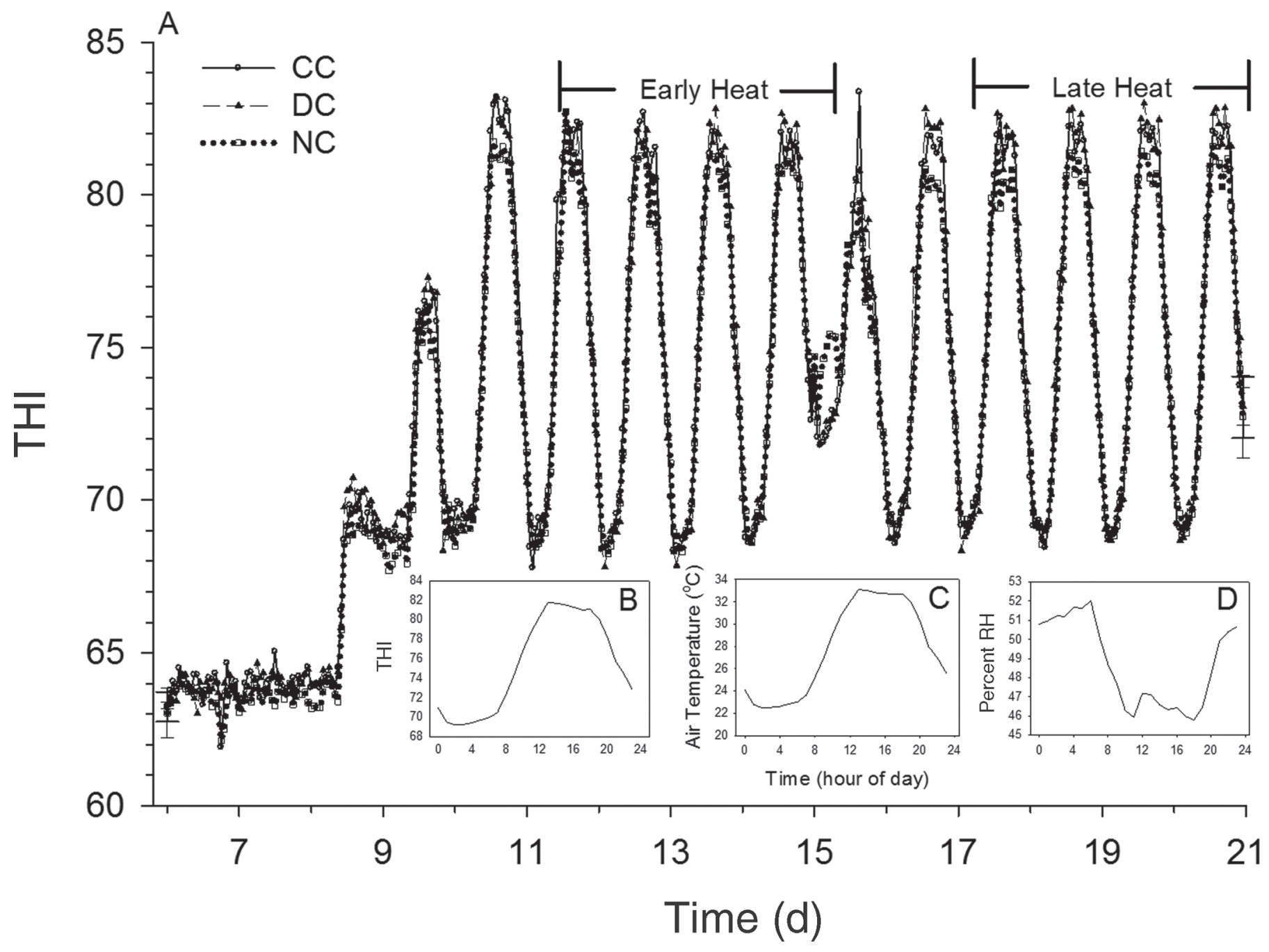

Figure 3. Average temperature-humidity index (THI) by hour and day of study is reported in panel A. Individual lines are presented for each treatment and represent an average of that treatment over the 3 trials of the study. The vertical lines through the first and last point on the $\mathrm{x}$-axis represent $\pm 1 \mathrm{SEM}$ for the treatment group. Baseline production values included d 6 and 7 at thermoneutrality. These values were averaged for each animal and used to determine change in production during the heat stress period, which is divided into early (d 11-14) and late (d 17-20). Panels B, C, and D show average THI, air temperature, and percent relative humidity (RH), respectively, values by hour of the day for the stable heat stress period (i.e., d 10 through 20). All values were averaged across treatments and periods of the study. CC $=$ continuous fan cooling; $\mathrm{DC}=8$-h day fan cooling from 1100 to $1900 \mathrm{~h}$; $\mathrm{NC}=8$-h night fan cooling from 2300 to $0700 \mathrm{~h}$. 
interactions of period and day with treatment. The denominator of $\mathrm{F}$ for treatment was the random effect of animal $\times$ trial within treatment, and the denominator of $\mathrm{F}$ for the subplot effects was the random effect of the residual mean square. Mean differences were determined using Fisher's protected least significant difference. The analyses were performed using PROC GLIMMIX in SAS (version 9.4, SAS Institute Inc., Cary, NC).

Heat flow data were analyzed as a randomized complete block design split plot in space and time as outlined by Steel et al. (1997). The complete block was animal identification. The linear statistical model contained the fixed effects of condition (i.e., AM fan, no AM fan, PM fan, no PM fan), skin site (i.e., shoulder, rump, tail), period (i.e., early, late), and all possible interactions. The random effect of animal $\times$ condition was used as the denominator of $\mathrm{F}$ for condition, the random effect of animal (condition skin site) was used as the denominator of $F$ for skin site and condition $x$ skin site, the random effect of animal $\times$ period was used as the denominator of $\mathrm{F}$ for period, the random effect of animal (condition $\times$ period) was used as the denominator of $\mathrm{F}$ for condition $\times$ period, and the random effect of animal (condition $\times$ skin $\times$ site $\times$ period) was used as the denominator for all other fixed effects interactions. Determination of mean differences and additional analyses were performed as earlier described. If the random variables had unequal variances or were not normally distributed (or both), a rank transformation was used as described by Conover and Iman (1981). However, all data are presented as actual values.

One of the factors in the linear statistical model was the blocking factor of animal identification. Each animal was considered a complete block in that each received all treatments with $12-1=11 \mathrm{df}$. The sum of squares (Ss) for animal was orthogonally partitioned into 2 parts. One part was chamber with 2 df ( 3 chambers -1 ). The other independent part was animals within chambers with $4-1 \mathrm{df}$ for each of 3 chambers giving $3+3+3=9$ df. Adding the Ss for chamber plus the Ss of animal (chamber) gives the Ss for animal with the associated $2+9=11 \mathrm{df}$. Thus chamber and animal (chamber) were both blocking factors. Animal (chamber) could have been used as the denominator of $\mathrm{F}$ for testing differences among chambers, but this was not the focus of this experiment.

\section{RESULTS AND DISCUSSION}

\section{Environmental Conditions}

It has been known for many years that cattle may tolerate a higher day ambient temperature if exposed to a cooler night ambient temperature, when rectal temperature is highest and there is a large thermal gradient for heat loss (Mendel et al., 1971; Scott et al., 1983; Gaughan et al., 2008). However, little attempt has been made to evaluate and quantify the physiological benefit of night versus day cooling under controlled environmental conditions and using a single mode of cooling as was performed in the present study.

Daily $\mathrm{T}_{\mathrm{a}}$ in the present study began cycling at 0700 $\mathrm{h}$, with an increase to the high of $33^{\circ} \mathrm{C}$ by $1300 \mathrm{~h}$. Beginning at $1900 \mathrm{~h}, \mathrm{~T}_{\mathrm{a}}$ decreased to the low of $23^{\circ} \mathrm{C}$, which occurred from 0200 to $0700 \mathrm{~h}$. This resulted in an average daily range in $\mathrm{T}_{a}$ of $10^{\circ} \mathrm{C}$. As a result of these cycles, the animals moved from the $\mathrm{TN}$ zone of $\mathrm{T}_{\mathrm{a}} 5$ to $25^{\circ} \mathrm{C}$, defined by Roenfeldt (1998), to a significant heat stress condition. It was important that a $\mathrm{T}_{\mathrm{a}}$ of $32^{\circ} \mathrm{C}$ was exceeded for each of the $4 \mathrm{~d}$ in both $\mathrm{E}$ and $\mathrm{L}$ periods to produce a reliable and repeatable stress environment. Others have noted that at a $\mathrm{T}_{\mathrm{a}}$ above $32^{\circ} \mathrm{C}$ cows gain sensible heat due to the reduced core to ambient thermal gradient (McLean, 1963; Gebremedhin and Wu, 2001) and external modes of heat loss (e.g., convective fan cooling) are required. Only maximum $\mathrm{T}_{\mathrm{a}}$ was different for the 3 treatment groups in this study, with the value for the $\mathrm{NC}$ group being $0.30^{\circ} \mathrm{C}$ higher than for $\mathrm{CC}$ or DC groups $(P \leq 0.05)$. An increase in mean, minimum, and maximum $\mathrm{T}_{\mathrm{a}}$ of 0.2 to $0.3^{\circ} \mathrm{C}$ occurred from $\mathrm{E}$ to $\mathrm{L}$ periods $(P \leq 0.05)$. The THI from d 6 through 20 is shown in Figure 3A, with an average daily minimum of 69 to a maximum of 82 during the heat stress period (Figure 3B). Average minimum-maximum THI values during HS for CC, DC, and NC groups were 67.2-83.5, 67.1-83.7, and 67.1-83.6, respectively.

\section{Heat Transfer}

The present study used direct measurements of heat flow at the skin-air interface for 3 body locations. These values represent a combination of heat transfer to the skin, usually by vasomotor activity, and heat loss to the air that is associated with fan action under different conditions in the cyclical heat stress environment. The effect of the fan, on or off, on heat transfer would be expected to remain constant during the entire heat stress period. Heat flow was measured using heat flow disks that have been used in humans (Layton et al., 1983; Giesbrecht et al., 2007) and pigs (Ingram, 1964; Mount and Ingram, 1965). Pigs were reported to have a heat flow rate of $150 \mathrm{~W} / \mathrm{m}^{2}$ at an air flow rate of $0.28 \mathrm{~m} / \mathrm{s}$ (Mount and Ingram, 1965). The cows in the present study were within the range of this earlier study with a maximum heat flow rate over $300 \mathrm{~W} / \mathrm{m}^{2}$ at the shoulder with an air flow rate measured at the 
fan of approximately $3.2 \mathrm{~m} / \mathrm{s}$ (Figure 4). No significant difference in overall heat flow was noted across trials $(P>0.05)$. Therefore, subsequent analyses used the combined results from the 3 trials. The expectation was that heat flow from all skin sites would decrease from cool to hot conditions due to a reduction in the thermal gradient for heat loss, as previously shown (Finch, 1985). Results from the present study showed that average heat flow with fans across all sites in the morning (AM), when $\mathrm{T}_{\mathrm{a}}$ averaged $23.8^{\circ} \mathrm{C}$, was more than double $\left(P \leq 0.05 ; 274 \pm 5 \mathrm{~W} / \mathrm{m}^{2}\right)$ the value using fans during the PM $\left(119 \pm 5 \mathrm{~W} / \mathrm{m}^{2}\right)$ at $\mathrm{T}_{\mathrm{a}} 33.3^{\circ} \mathrm{C}$. Interestingly, AM heat flow with no fans $\left(130 \pm 5 \mathrm{~W} / \mathrm{m}^{2}\right)$ was not different $(P \geq 0.05)$ from the afternoon $(\mathrm{PM})$ value at $\mathrm{T}_{\mathrm{a}} 33.3^{\circ} \mathrm{C}$ with fans $\left(119 \pm 5 \mathrm{~W} / \mathrm{m}^{2}\right)$. These results show the increased benefit of using fans at a cooler $\mathrm{T}_{\mathrm{a}}$ for increased heat loss efficiency. No fan ventilation in the heat $\left(\mathrm{T}_{\mathrm{a}} 33.2^{\circ} \mathrm{C}\right)$ resulted in a similar proportional increase in heat flow, as was noted in the cool morning environment.

Average heat flow, combining fan and no fan use, at the 3 skin sites showed no difference $(P \geq 0.05)$ between rump $\left(149 \pm 3 \mathrm{~W} / \mathrm{m}^{2}\right)$ and shoulder $(154 \pm 3$ $\left.\mathrm{W} / \mathrm{m}^{2}\right)$ regions, with both being slightly greater $(P \leq$ $0.05)$ than for tail $\left(140 \pm 3 \mathrm{~W} / \mathrm{m}^{2}\right)$. Heat flow at the
3 skin sites during cool morning and hot afternoon is shown in Figure 4. Site differences in heat flow are due to the combination of regional blood flow, proximity of blood vessels to skin surface, and the "body surface law" (Kleiber, 1932). An appendage, such as the tail, would have increased heat loss compared with the trunk due to it being highly vascularized, as in the rat (Raman, Roberts, and Vanhuyse, 1983), having closer proximity of blood flow to the skin (Ingram and Whittow, 1963; Mount, 1979), and having a larger surface area to mass ratio (Cossins and Bowler, 1987; Curtis, 1983). In fact, the use of fans in the present study benefited the shoulder region more than the other sites at the cool $\mathrm{T}_{\mathrm{a}}$. This was expected because the fans were positioned over the heads of the animals, which caused air movement to flow from the shoulder to the tail. Therefore, the skin at the shoulder experienced the highest air speed. Interestingly, the benefit derived from position to the fan was not realized at the hot $\mathrm{T}_{a}$, with shoulder heat flow $\left(131 \pm 6 \mathrm{~W} / \mathrm{m}^{2}\right)$ equaling the rump (120 \pm $\left.6 \mathrm{~W} / \mathrm{m}^{2}\right)$ and rump equaling the tail $\left(105 \pm 6 \mathrm{~W} / \mathrm{m}^{2}\right)$ values $(P \geq 0.05)$. This was likely due to the extremely reduced thermal gradient for heat loss during HS that could not be ameliorated by body structure or blood flow.

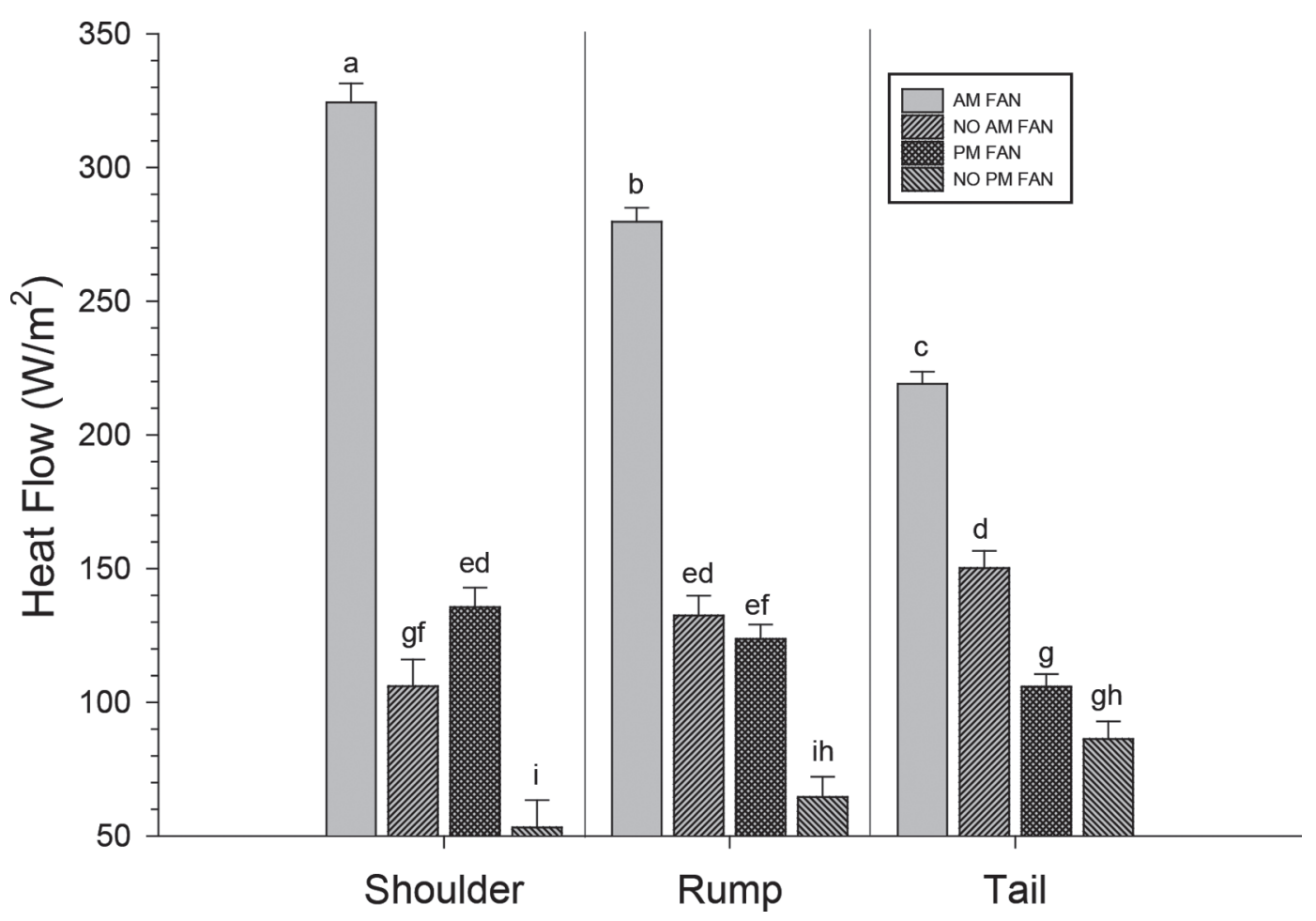

Figure 4. Average heat flow for the 4 fan conditions at the 3 skin sites across the 3 trials of the study. Heat flow for each animal was averaged to derive a value for each fan condition and site, for a total of 12 values per animal. The abbreviation AM represents values determined at 0500 to $0700 \mathrm{~h}$, and PM represents values measured at 1500 to $1700 \mathrm{~h}$. Statistical analyses were performed on these values. Bars across site and fan condition with the same letter are not significantly different at $P \geq 0.05$. Error bars represent \pm 1 SEM. 
A comparison of overall shift in heat flow from the combined skin sites from E $\left(149 \pm 3 \mathrm{~W} / \mathrm{m}^{2}\right)$ to $\mathrm{L}(147$ $\left.\pm 3 \mathrm{~W} / \mathrm{m}^{2}\right)$ heat exposure periods showed no change $(P$ $>0.05$ ). Separation of these values for $\mathrm{E}$ and $\mathrm{L}$ periods between $\mathrm{AM}$ and PM with and without fans identified the only change $(P \leq 0.05)$ as being E AM fan $(291 \pm$ $\left.5 \mathrm{~W} / \mathrm{m}^{2}\right)$ versus $\mathrm{L}$ AM fan $\left(258 \pm 5 \mathrm{~W} / \mathrm{m}^{2}\right)$. A more detailed examination determined that the reductions were attributable to rump E AM fan $\left(298 \pm 8 \mathrm{~W} / \mathrm{m}^{2}\right)$ versus L AM fan $\left(261 \pm 8 \mathrm{~W} / \mathrm{m}^{2} ; P \leq 0.05\right)$, and shoulder E AM fan $\left(348 \pm 8 \mathrm{~W} / \mathrm{m}^{2}\right)$ versus L AM fan (301 $\left.\pm 8 \mathrm{~W} / \mathrm{m}^{2} ; P \leq 0.05\right)$. No time-related differences were observed for the tail site, during the PM for any site, or for the time where no fans were used. The absence of differences during the times when no fans were used would suggest that no change occurred in the physiological or physical characteristics of the 3 skin sites over time. Instead, a shift occurred in the interaction between the fans and skin during the cool hours of the daily cycle for the trunk cutaneous regions $(P \leq 0.05)$. There is no explanation for these isolated changes that suggests any type of adaptation.

\section{Production}

Measurement of heat flow from various skin sites, with and without fans, has shown the benefit of fan cooling especially at different times of the day (Figure 4). It was expected that such a benefit would result in changes in productivity. One of the primary measure- ments of productivity is DMI. In the present study, no differences were observed in average DMI $(\mathrm{kg} / \mathrm{d} ; P \geq$ $0.10)$ across treatment groups over the last $2 \mathrm{~d}$ at thermoneutrality before HS. Likewise, DMI for the entire HS period was not different across treatment groups (Table $2 ; P \geq 0.10$ ). However, it is important to consider the individual variation within each group before treatment that might carry forward into the treatment period. One way to accomplish this relationship is to examine the change in productivity, such as DMI, from the pretreatment, TN level. Percent changes in DMI values from average baseline levels of 38.2, 41.6, and $41.6 \pm 2.0 \mathrm{~kg} / \mathrm{d}$ for CC, DC, and NC groups, respectively, are separated in Table 2 . The trend for a percent reduction in DMI was more than double $(P \leq 0.10)$ for both $\mathrm{DC}$ and $\mathrm{NC}$ groups compared with the CC groups to show that continuous cooling with fans was more effective than partial day cooling at any time of the day in diminishing the heat-induced reduction in DMI. Gaughan et al. (2008) showed in beef cattle that the use of fans and sprinklers for night cooling during heat stress maintained DMI at TN levels while lowering $\mathrm{T}_{\mathrm{re}}$ and RR. However, their study used only $4 \mathrm{~d}$ of heat stress and multiple modes of cooling. A consideration of the actual DMI and percent decline from baseline levels in the present study showed no change from $\mathrm{E}$ to L periods of HS (Table $3 ; P \geq 0.10$ ). A further breakdown of the period results for DMI into the 3 treatment groups showed no change from $\mathrm{E}$ to $\mathrm{L}$ periods (Table $4 ; P \geq 0.10)$. It was concluded that DMI showed no

Table 2. Average daily feed intake and milk production during heat stress under different treatments

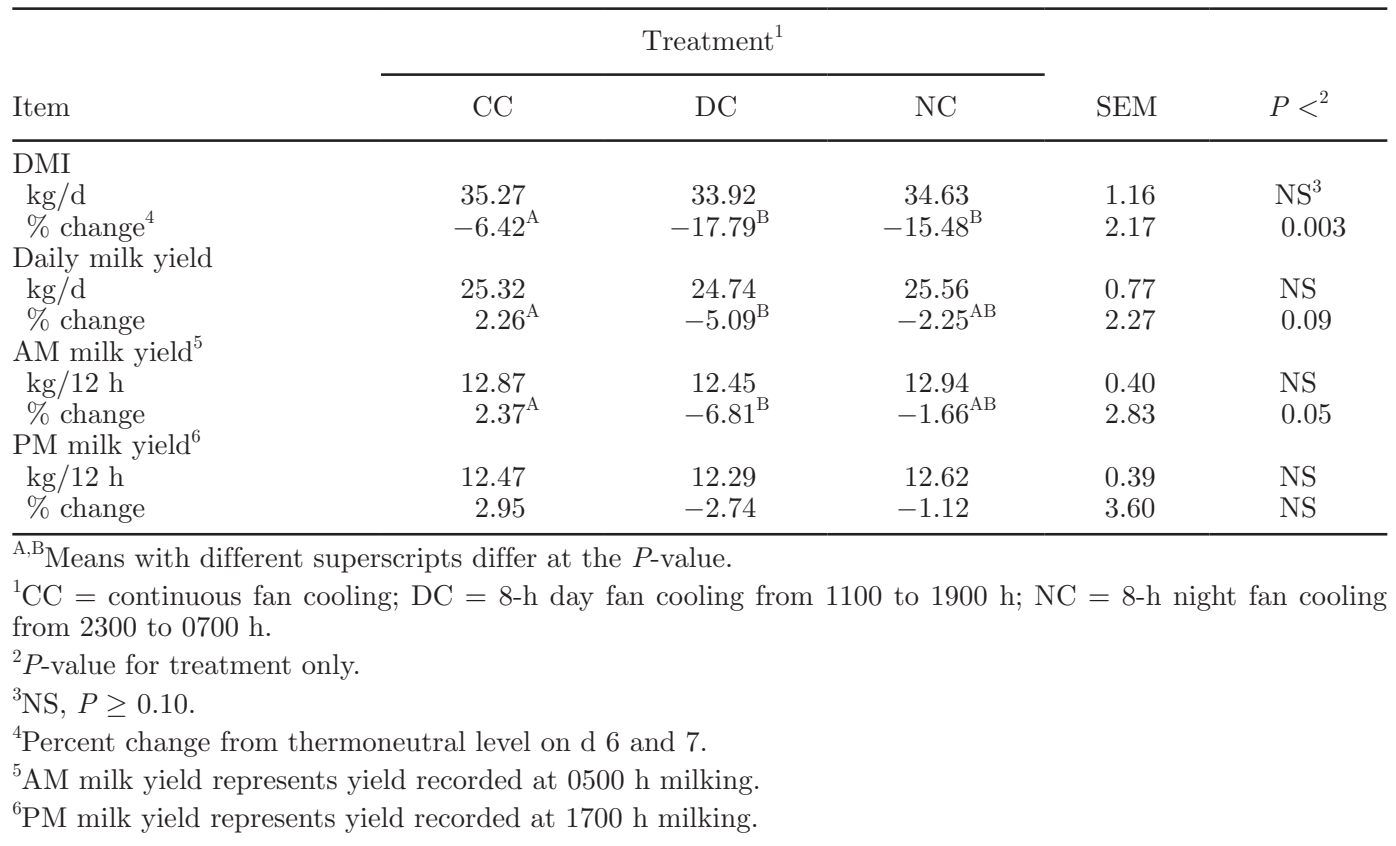


Table 3. Period differences in feed intake and milk production during heat stress

\begin{tabular}{|c|c|c|c|c|}
\hline \multirow[b]{2}{*}{ Item } & \multicolumn{2}{|c|}{ Period $^{1}$} & \multirow[b]{2}{*}{ SEM } & \multirow[b]{2}{*}{$P<^{2}$} \\
\hline & Early & Late & & \\
\hline \multicolumn{5}{|l|}{ DMI } \\
\hline $\mathrm{kg} / \mathrm{d}$ & 34.52 & 34.71 & 0.91 & $\mathrm{NS}^{3}$ \\
\hline$\%$ change $^{4}$ & -13.72 & -12.69 & 1.83 & NS \\
\hline \multicolumn{5}{|c|}{ Daily milk yield } \\
\hline $\mathrm{kg} / \mathrm{d}$ & 25.52 & 24.89 & 0.83 & 0.003 \\
\hline \% change & -0.4 & -2.98 & 1.66 & 0.003 \\
\hline \multicolumn{5}{|c|}{ AM milk yield ${ }^{5}$} \\
\hline $\mathrm{kg} / 12 \mathrm{~h}$ & 12.87 & 12.63 & 0.24 & 0.05 \\
\hline$\%$ change & -1.00 & -3.07 & 1.72 & 0.05 \\
\hline \multicolumn{5}{|c|}{ PM milk yield ${ }^{6}$} \\
\hline $\mathrm{kg} / 12 \mathrm{~h}$ & 12.65 & 12.26 & 0.23 & 0.004 \\
\hline$\%$ change & 1.24 & -1.85 & 2.15 & 0.009 \\
\hline
\end{tabular}

${ }^{1}$ Early $=\mathrm{d} 11$ to 14 ; late $=\mathrm{d} 17$ to 20.

${ }^{2}$ Effect $=P$-value for period only.

${ }^{3} \mathrm{NS}, P>0.10$

${ }^{4}$ Percent change from thermoneutral level on d 6 and 7 .

${ }^{5} \mathrm{AM}$ milk yield represents yield recorded at $0500 \mathrm{~h}$ milking.

${ }^{6} \mathrm{PM}$ milk yield represents yield recorded at $1700 \mathrm{~h}$ milking.

significant heat adaptation over the 11-d HS period, after the initial decline occurred.

Expression of milk yield (daily, AM, PM) as kilograms per day showed no difference across treatment groups (Table $2 ; P \geq 0.10$ ). The change from the baseline TN level was more informative. Pre-exposure levels for total daily milk yield were $24.9,26.2$, and $26.4 \pm 1.6 \mathrm{~kg} / \mathrm{d}(P$ $\leq 0.10)$ for CC, DC, and NC groups, respectively. Both $\mathrm{DC}$ and $\mathrm{NC}$ groups had percent change milk yields that were similar (Table 2; $P \geq 0.10$ ), with the DC group being below CC (Table 2; $P \leq 0.05$ ). More importantly, percent change values for $\mathrm{NC}$ and $\mathrm{CC}$ groups were not different from each other $(P \geq 0.10)$. The differences in total daily milk yield were attributed to the AM milk production because the percent change values were similar in magnitude to the daily value. No differences (Table $2 ; P \geq 0.10$ ) were observed for the percent change in PM milk yield.

Reductions were observed in all milk yield values from E to L periods of HS (Table 3). Actual values for total daily milk yield decreased over time $(P \leq 0.05)$. The percent change from pre-exposure, TN level also showed a reduction over time for both AM and PM measurements (Table 3; $P \leq 0.05$ ). This suggests that milk production is more sensitive than DMI to the temporal effects of HS, and is supported by recent studies showing that only 35 to $50 \%$ of the heat-induced reduction in milk production in Holstein cows can be attributed to a reduction in nutrient intake (Rhoads et al., 2009; Wheelock et al., 2010). An examination of the $\mathrm{E}$ to L effects of HS on milk production for the 3 treatment groups is shown in Table 4. Again, there appeared to be no evidence of adaptation for the PM milk yield over the $11 \mathrm{~d}$ of HS for any group. In contrast, the DC

Table 4. Average daily feed intake and milk production by treatment and period interaction during heat stress

\begin{tabular}{|c|c|c|c|c|c|c|c|c|}
\hline \multirow[b]{3}{*}{ Item } & \multicolumn{6}{|c|}{ Treatment $^{1}$} & \multirow[b]{3}{*}{ SEM } & \multirow[b]{3}{*}{$P<{ }^{2}$} \\
\hline & \multicolumn{2}{|c|}{$\mathrm{CC}$} & \multicolumn{2}{|c|}{$\mathrm{DC}$} & \multicolumn{2}{|c|}{$\mathrm{NC}$} & & \\
\hline & Early & Late & Early & Late & Early & Late & & \\
\hline \multicolumn{9}{|l|}{$\overline{\mathrm{DMI}}$} \\
\hline $\mathrm{kg} / \mathrm{d}$ & 34.79 & 35.75 & 34.18 & 33.71 & 34.60 & 34.67 & 1.22 & $\mathrm{NS}^{3}$ \\
\hline$\%$ change $^{4}$ & $-7.94^{\mathrm{A}}$ & $-4.90^{\mathrm{A}}$ & $-17.46^{\mathrm{B}}$ & $-18.11^{\mathrm{B}}$ & $-15.8^{\mathrm{B}}$ & $-15.17^{\mathrm{B}}$ & 2.37 & 0.10 \\
\hline \multicolumn{9}{|l|}{ Daily milk yield } \\
\hline $\mathrm{kg} / \mathrm{d}$ & 25.39 & 25.25 & 25.28 & 24.20 & 25.91 & 25.21 & 0.79 & NS \\
\hline$\%$ change & 2.87 & 1.65 & -3.19 & -6.98 & -0.89 & -3.61 & 2.38 & NS \\
\hline \multicolumn{9}{|l|}{ AM milk yield ${ }^{5}$} \\
\hline $\mathrm{kg} / 12 \mathrm{~h}$ & $12.78^{\mathrm{AB}}$ & $12.97^{\mathrm{AB}}$ & $12.78^{\mathrm{A}}$ & $12.11^{\mathrm{B}}$ & $13.06^{\mathrm{AB}}$ & $12.81^{\mathrm{AB}}$ & 0.42 & 0.08 \\
\hline \multirow{2}{*}{\multicolumn{9}{|c|}{ PM milk yield ${ }^{6}$}} \\
\hline & & & & & & & & \\
\hline $\mathrm{kg} / 12 \mathrm{~h}$ & 12.61 & 12.28 & 12.50 & 12.09 & 12.84 & 12.40 & 0.40 & NS \\
\hline$\%$ change & 4.56 & 1.33 & -1.38 & -4.09 & 0.54 & -2.78 & 3.73 & NS \\
\hline
\end{tabular}

${ }_{\mathrm{A}, \mathrm{B}}$ Means with different superscripts differ at the $P$-value.

${ }^{1} \mathrm{CC}=$ continuous fan cooling; $\mathrm{DC}=8$-h day fan cooling from 1100 to $1900 \mathrm{~h}$; $\mathrm{NC}=8$-h night fan cooling from 2300 to $0700 \mathrm{~h}$; early $=\mathrm{d} 11$ to 14 ; late $=\mathrm{d} 17$ to 20 .

${ }^{2}$ Effect of treatment by period.

${ }^{3} \mathrm{NS}, P>0.10$.

${ }^{4}$ Percent change from thermoneutral level on $\mathrm{d} 6$ and 7 .

${ }^{5} \mathrm{AM}$ milk yield represents yield recorded at $0500 \mathrm{~h}$ milking.

${ }^{6} \mathrm{PM}$ milk yield represents yield recorded at $1700 \mathrm{~h}$ milking. 
Table 5. Average daily body temperatures and respiration rate during heat stress under different treatments

\begin{tabular}{|c|c|c|c|c|}
\hline \multirow[b]{2}{*}{ Item } & \multicolumn{3}{|c|}{ Treatment $^{1}$} & \multirow[b]{2}{*}{ SEM } \\
\hline & $\mathrm{CC}$ & $\mathrm{DC}$ & $\mathrm{NC}$ & \\
\hline \multicolumn{5}{|c|}{ Rectal temperature $\left({ }^{\circ} \mathrm{C}\right)$} \\
\hline Mean & $38.88^{\mathrm{A}}$ & $39.33^{\mathrm{B}}$ & $39.28^{\mathrm{B}}$ & 0.07 \\
\hline Minimum & $38.43^{\mathrm{A}}$ & $38.87^{\mathrm{B}}$ & $38.45^{\mathrm{A}}$ & 0.06 \\
\hline Maximum & $39.22^{\mathrm{A}}$ & $39.68^{\mathrm{B}}$ & $39.81^{\mathrm{B}}$ & 0.08 \\
\hline Range & $0.79^{\mathrm{A}}$ & $0.81^{\mathrm{A}}$ & $1.36^{\mathrm{B}}$ & 0.06 \\
\hline \multicolumn{5}{|c|}{ Respiration rate (breaths per min) } \\
\hline Mean & $62.90^{\mathrm{A}}$ & $73.57^{\mathrm{B}}$ & $74.76^{\mathrm{B}}$ & 1.59 \\
\hline Minimum & $49.53^{\mathrm{A}}$ & $60.04^{\mathrm{B}}$ & $54.02^{\mathrm{C}}$ & 1.39 \\
\hline Maximum & $76.25^{\mathrm{A}}$ & $86.82^{\mathrm{B}}$ & $92.57^{\mathrm{C}}$ & 1.9 \\
\hline Range & $26.70^{\mathrm{A}}$ & $26.44^{\mathrm{A}}$ & $38.23^{\mathrm{B}}$ & 1.4 \\
\hline \multicolumn{5}{|c|}{ Ear temperature $\left({ }^{\circ} \mathrm{C}\right)$} \\
\hline Mean & $36.18^{\mathrm{A}}$ & $36.84^{\mathrm{B}}$ & $36.60^{\mathrm{C}}$ & 0.06 \\
\hline Minimum & $34.98^{\mathrm{A}}$ & $35.87^{\mathrm{B}}$ & $34.82^{\mathrm{A}}$ & 0.12 \\
\hline Maximum & $37.18^{\mathrm{A}}$ & $37.59^{\mathrm{B}}$ & $37.80^{\mathrm{C}}$ & 0.04 \\
\hline Range & $2.22^{\mathrm{A}}$ & $1.72^{\mathrm{B}}$ & $2.98^{\mathrm{C}}$ & 0.14 \\
\hline \multicolumn{5}{|c|}{ Tail temperature $\left({ }^{\circ} \mathrm{C}\right)$} \\
\hline Mean & $34.94^{\mathrm{A}}$ & $35.78^{\mathrm{B}}$ & $35.25^{\mathrm{C}}$ & 0.07 \\
\hline Minimum & $33.25^{\mathrm{A}}$ & $34.55^{\mathrm{B}}$ & $32.93^{\mathrm{C}}$ & 0.11 \\
\hline Maximum & $36.21^{\mathrm{A}}$ & $36.76^{\mathrm{B}}$ & $36.83^{\mathrm{B}}$ & 0.08 \\
\hline Range & $2.96^{\mathrm{A}}$ & $2.21^{\mathrm{B}}$ & $3.90^{\mathrm{C}}$ & 0.12 \\
\hline \multicolumn{5}{|c|}{ Shoulder temperature $\left({ }^{\circ} \mathrm{C}\right)$} \\
\hline Mean & $35.35^{\mathrm{A}}$ & $36.59^{\mathrm{B}}$ & $36.17^{\mathrm{C}}$ & 0.09 \\
\hline Minimum & $33.63^{\mathrm{A}}$ & $35.60^{\mathrm{B}}$ & $33.45^{\mathrm{A}}$ & 0.15 \\
\hline Maximum & $36.69^{\mathrm{A}}$ & $37.40^{\mathrm{B}}$ & $37.86^{\mathrm{C}}$ & 0.07 \\
\hline Range & $3.06^{\mathrm{A}}$ & $1.82^{\mathrm{B}}$ & $4.44^{\mathrm{C}}$ & 0.14 \\
\hline \multicolumn{5}{|c|}{ Rump temperature $\left({ }^{\circ} \mathrm{C}\right)$} \\
\hline Mean & $35.56^{\mathrm{A}}$ & $36.73^{\mathrm{B}}$ & $36.31^{\mathrm{C}}$ & 0.07 \\
\hline Minimum & $33.89^{\mathrm{A}}$ & $35.66^{\mathrm{B}}$ & $33.80^{\mathrm{A}}$ & 0.12 \\
\hline Maximum & $36.87^{\mathrm{A}}$ & $37.56^{\mathrm{B}}$ & $37.90^{\mathrm{C}}$ & 0.06 \\
\hline Range & $2.98^{\mathrm{A}}$ & $1.92^{\mathrm{B}}$ & $4.08^{\mathrm{C}}$ & 0.11 \\
\hline
\end{tabular}

group displayed a trend for an $\mathrm{E}$ to $\mathrm{L}$ reduction in $\mathrm{AM}$ milk yield (Table $4 ; P=0.08$ ). It appears from these results that night cooling was more effective than day cooling in reducing the temporal effects of heat stress over an 11-d period. The next question is whether a thermal stimulus might explain these differences in milk production.

\section{Thermoregulation}

The thermal status of cows was estimated to determine the correlates with heat-stress-related changes in animal production for the different fan treatments. Hansen (1994) noted that body temperature is superior to ambient variables as a determinant of animal performance in the heat, with milk production being negatively correlated with an increase in core temperature above $39^{\circ} \mathrm{C}$ (Berman et al., 1985; Silankove, 2000). In the present study, maximum daily $\mathrm{T}_{\mathrm{re}}$ exceeded $39^{\circ} \mathrm{C}$ for all treatments, including the CC group (Table 5). However, the CC group continued to increase milk pro- duction during heat stress likely due to the minimum daily $\mathrm{T}_{\mathrm{re}}$ dropping to $38.4^{\circ} \mathrm{C}$ at night. This indicates that it is insufficient to measure a single mean $T_{\text {re }}$ without accounting for the daily fluctuation and potential cooling at night. The DC fan treatment group had a mean, minimum, and maximum $\mathrm{T}_{\mathrm{re}}$ during heat stress that exceeded $(P \leq 0.05)$ these values for the $\mathrm{CC}$ group. Likewise, the change in daily and AM milk yields for the DC group were well below the CC group (Table 2). Mean and maximum $\mathrm{T}_{\mathrm{re}}$ for the NC group were similar to values for the DC group $(P \geq 0.05)$, and higher than for the CC treatment group $(P \leq 0.05)$. Importantly, the minimum $\mathrm{T}_{\mathrm{re}}$ was similar $(P \geq 0.05)$ for the $\mathrm{NC}$ and CC groups. This agreed with the change in daily and AM milk yields that were identical $(P \geq 0.05)$ for the $\mathrm{NC}$ and CC groups.

Little change occurred in $\mathrm{T}_{\mathrm{re}}$ from $\mathrm{E}$ to $\mathrm{L}$ periods to suggest adaptation to HS (Table 6). All changes from $\mathrm{E}$ to $\mathrm{L}$ periods were less than $0.10^{\circ} \mathrm{C}$ and not considered to be biologically significant. The mean change in $\mathrm{T}_{\mathrm{re}}$ was not significant, and the significant change in maxi- 
mum $\mathrm{T}_{\mathrm{re}}(P \leq 0.05)$ was only $0.08^{\circ} \mathrm{C}$. These changes from $\mathrm{E}$ to $\mathrm{L}$ periods were less than the daily circadian fluctuations in core temperature for dairy cows under TN (Bitman et al., 1984; Kendall and Webster, 2009) or heat stress (Settivari et al., 2007) conditions.

Rectal temperature range has been reported for dairy cows exposed to heat stress. de Andrade Ferrazza et al. (2017) noted that Holstein cows exposed to a constant thermal stress of $36.3^{\circ} \mathrm{C}$ ambient temperature and $61 \%$ relative humidity had a $\mathrm{T}_{\mathrm{re}}$ range of $0.85^{\circ} \mathrm{C}$ from morning to afternoon. Berman and Morag (1971) found a slightly higher $\mathrm{T}_{\mathrm{re}}$ range of $1.20^{\circ} \mathrm{C}$ for dairy cows exposed to summer conditions. In the present study, the $\mathrm{T}_{\mathrm{re}}$ range for $\mathrm{CC}$ and $\mathrm{DC}$ groups differed by only $0.02^{\circ} \mathrm{C}(P \geq 0.05)$, whereas the NC group was $0.56^{\circ} \mathrm{C}(P \leq 0.05)$ greater than the other groups (Table $5)$. The larger range for the NC group was because the fans were on these cows during the cooler night and turned off during the hottest portion of the day. The relative range in daily $T_{\text {re }}$ by itself, therefore, may be less important in determining milk yield, because the
CC and DC groups were different for milk yield (Table 2 ), but identical for $\mathrm{T}_{\mathrm{re}}$ range (Table 5 ). The absolute daily low body temperature (rectal or skin) may be an important determinant of milk production.

Respiration rate is an effector output of the thermoregulatory control system that is an important element of the respiratory heat exchange process. The RR and has been used in cattle as a sensitive indicator of thermal load (Scharf et al., 2010) that is an easier to obtain than core body temperature outside of the controlled thermal environment (Gaughan et al., 2000). Berman et al. (1985) noted that RR in the dairy cow starts to rise above 50 to $60 \mathrm{bpm}$ when ambient temperature surpasses $25^{\circ} \mathrm{C}$. They suggested that respiratory evaporative heat loss is more important than cutaneous heat exchange in large cattle for maintenance of thermal stability due to their large body size. More recently, Maia et al. (2005) suggested otherwise and concluded that cutaneous evaporation is the dominant avenue for heat loss at $\mathrm{T}_{\mathrm{a}}$ above $30^{\circ} \mathrm{C}$ and accounting for approximately $85 \%$ of the total heat loss. The remaining $15 \%$

Table 6. Period differences in body temperature and respiration rate during heat stress

\begin{tabular}{|c|c|c|c|c|}
\hline \multirow[b]{2}{*}{ Item } & \multicolumn{2}{|c|}{ Period $^{1}$} & \multirow[b]{2}{*}{ SEM } & \multirow[b]{2}{*}{$P<^{2}$} \\
\hline & Early & Late & & \\
\hline \multicolumn{5}{|c|}{ Rectal temperature $\left({ }^{\circ} \mathrm{C}\right)$} \\
\hline Mean & 39.19 & 39.14 & 0.04 & $\mathrm{NS}^{3}$ \\
\hline Minimum & 38.59 & 38.58 & 0.04 & NS \\
\hline Maximum & 39.61 & 39.53 & 0.05 & 0.04 \\
\hline Range & 1.02 & 0.95 & 0.04 & NS \\
\hline \multicolumn{5}{|c|}{ Respiration rate (breaths per min) } \\
\hline Mean & 71.38 & 69.43 & 1.08 & NS \\
\hline Minimum & 56.18 & 53.33 & 1.00 & NS \\
\hline Maximum & 85.01 & 85.42 & 1.34 & NS \\
\hline Range & 28.83 & 32.08 & 1.15 & NS \\
\hline \multicolumn{5}{|c|}{ Ear temperature $\left({ }^{\circ} \mathrm{C}\right)$} \\
\hline Mean & 36.56 & 36.52 & 0.05 & NS \\
\hline Minimum & 35.29 & 35.15 & 0.10 & NS \\
\hline Maximum & 37.52 & 37.52 & 0.04 & NS \\
\hline Range & 2.25 & 2.36 & 0.10 & NS \\
\hline \multicolumn{5}{|c|}{ Tail temperature $\left({ }^{\circ} \mathrm{C}\right)$} \\
\hline Mean & 35.51 & 35.14 & 0.05 & 0.0001 \\
\hline Minimum & 33.78 & 33.37 & 0.08 & 0.0001 \\
\hline Maximum & 36.75 & 36.45 & 0.05 & 0.0001 \\
\hline Range & 2.97 & 3.08 & 0.09 & NS \\
\hline \multicolumn{5}{|c|}{ Shoulder temperature $\left({ }^{\circ} \mathrm{C}\right)$} \\
\hline Mean & 36.16 & 35.9 & 0.06 & 0.0001 \\
\hline Minimum & 34.39 & 34.04 & 0.11 & 0.008 \\
\hline Maximum & 37.44 & 37.2 & 0.05 & 0.0001 \\
\hline Range & 3.05 & 3.16 & 0.10 & NS \\
\hline \multicolumn{5}{|c|}{ Rump temperature $\left({ }^{\circ} \mathrm{C}\right)$} \\
\hline Mean & 36.27 & 36.13 & 0.05 & 0.035 \\
\hline Minimum & 34.54 & 34.35 & 0.09 & NS \\
\hline Maximum & 37.51 & 37.38 & 0.05 & 0.04 \\
\hline Range & 2.96 & 3.02 & 0.08 & NS \\
\hline
\end{tabular}


was attributed to respiratory evaporative heat loss. Regardless of the specific region, there is agreement that evaporative heat loss becomes extremely important for the heat-stressed dairy cow. In the present study, average $\mathrm{RR}$ ranged from 55 to $85 \mathrm{bpm}$ throughout the HS period and was characteristic of Holstein cows exposed to heat stress (Correa-Calderon et al., 2004). Both DC and NC groups displayed mean, minimum, and maximum RR values that were greater $(P \leq 0.05)$ than for the CC group (Table 5). Respiration rate for the NC group was either equal to (i.e., mean value), below (i.e., minimum value), or above (i.e., maximum value) the DC group during heat exposure. The shift in minimum and maximum between DC and NC groups was a reflection of the fans being off or on when the values were determined for each group. For example, the fans were off for the NC group during the peak of daily heat exposure and so maximum RR would have been greater than for the DC group. The reverse would be true for the DC group when the minimum RR which was determined at night.

What was uniquely greater $(P \leq 0.05)$ for the $\mathrm{NC}$ group compared with the $\mathrm{CC}$ and $\mathrm{DC}$ groups was the daily range of both $\mathrm{T}_{\mathrm{re}}$ and $\mathrm{RR}$, which were more than $0.50^{\circ} \mathrm{C}$ and $10 \mathrm{bpm}$, respectively, above the other groups. It is likely that the increased resilience in heat exchange of the NC group was sufficient to offset the daily heat stress to result in a daily milk yield that was similar to that of the CC group (Table 2). One should be careful about equating $\mathrm{RR}$ with respiratory heat flow, however, because heat exchange across this avenue is also dependent on the respiratory volume, which is independent of rate (Curtis, 1983; Berman, 2005).

Respiration rate of animals in the present study exhibited few changes indicative of heat stress adaptation from $\mathrm{E}$ to $\mathrm{L}$ periods (Table 6). Only minimum $\mathrm{RR}$ and $\mathrm{RR}$ range changed during heat stress $(P \leq$ 0.05). In both cases, the shifts were not considered to be physiologically significant. In addition, there were no interactions between treatment group and period $(P$ $\geq 0.05)$ for any RR measurement.

Skin temperature is a potential input into the thermoregulatory system that represents an integration of several physical and physiological factors (e.g., hair coat properties, $\mathrm{T}_{\mathrm{a}}$, cutaneous vasomotion, and sweat rate). In addition, several of these factors are interrelated. Blazquez et al. (1994) suggested that increased blood flow to the skin in cattle is positively correlated with an increase in sweat rate. Likewise, an increase in the skin temperature of dairy cows is associated with an increase in sweating rate (Shearer and Beede, 1990). Gebremedhin et al. (2010) reported that skin temperature is the driving force for moisture production at the level of the skin. It has recently been suggested
(Romanovsky, 2014) that skin temperature "serves as a feedforward signal for a complex behavior with a thermoregulatory component." Skin temperature more directly reflects the ambient condition than internal body temperature and could have a more direct effect on animal productivity as a feedforward agent. Daily skin temperatures averaged over the entire HS period for the 4 sites and 3 treatment groups are shown in Table 5. Mean temperatures for all sites ranked the CC group as the lowest and the DC group as the highest $(P \leq 0.05)$. Maximum temperatures for tail, shoulder, and rump sites were the highest for NC group, which was 0.20 to $0.40^{\circ} \mathrm{C}$ above the DC group $(P \leq 0.05)$. As noted for $\mathrm{RR}$, this was because the maximum measurements were made for the NC group when the fans were turned off. More important was the fact that minimum skin temperature for these 3 sites was the same for $\mathrm{CC}$ and $\mathrm{NC}$ groups $(P \geq 0.05)$. Finally, range of skin temperature at all sites for the DC group surpassed $(P$ $\leq 0.05)$ the other treatment groups.

There was an indication of adaptation in the skin temperature of some sites with the shift from E to L periods of heat stress (Table 6). It should be noted that mean, maximum, and minimum $\mathrm{T}_{\mathrm{a}}$ values increased $(P$ $\leq 0.05)$ by $0.25,0.31$, and $0.24^{\circ} \mathrm{C}$, respectively, from $\mathrm{E}$ to $\mathrm{L}$ periods. Mean, maximum, and minimum tail and shoulder skin temperatures, instead of increasing with $\mathrm{T}_{\mathrm{a}}$, actually decreased from $\mathrm{E}$ to $\mathrm{L}$ periods $(P$ $\leq 0.05)$, in addition to a similar reduction in mean and maximum rump skin temperatures over the same time. This would suggest either a reduction in cutaneous heat loss, possibly due to reduced peripheral blood flow, or an increase in sweat rate. Both changes would decrease skin temperature. Several studies in humans (Roberts et al., 1977; Yamazaki and Hamasaki, 2003) have shown that 6 to $10 \mathrm{~d}$ of exercise in the heat results in a reduction in the core body temperature threshold for cutaneous vasodilation and sweating. Nadel et al. (1974) suggested that such a downward shift likely is due to an adjustment in the central nervous system. Alternatively, a reduction in metabolic heat production early during exposure to heat stress would result in a reduced need for cutaneous heat loss, an unchanged core temperature, over time such as seen in the present study (Table 6). Heat-induced reduction in energy metabolism is reported to occur in cattle from between 3 and $4 \mathrm{~d}$ (Nienaber and Hahn, 2007) to the second week of heat exposure (Kibler et al., 1965). An increase in sweat rate without a change in metabolic heat production might also reduce skin temperature, due to increased cutaneous evaporative cooling, over time in the heat. Kadzere et al. (2002) noted that heat adaptability in lactating dairy cows is due, in part, to an increase in the number of active sweat glands. 
The only significant interaction between treatment and period was for the NC treatment group. Maximum ear and tail skin temperatures, representing the extremities, decreased by 0.20 and $0.52^{\circ} \mathrm{C}(P \leq 0.05)$, respectively, from $\mathrm{E}$ to $\mathrm{L}$ heat stress periods. The maximum skin temperature for this treatment group would have occurred during a time of day when the fans were off. Therefore, an increase in convective heat loss from the skin, due to fan cooling, would not have been a factor. Although no information is available for cows on the activity or number of sweat glands per unit of skin surface area in the extremities, one would expect that the numbers would be less than for the trunk. The reduction in skin temperature of the extremities and not the trunk sites would argue against the possibility of an increase in sweat rate being the contributor. The extremities are superior to other skin sites in terms of cutaneous blood flow that is augmented during heat stress. An increase in blood flow to the extremities occurs during heat stress before deep body temperature increases (Beakley and Findlay, 1955; Ingram and Whittow, 1962; Whittow, 1962) and plays an important role in the regulation of heat loss to the environment. The increased flow into the extremities is associated with the opening of arteriovenous anastomoses in these areas (Ingram and Mount, 1975). A close association of arteries and veins in the anastomoses facilitates vascular heat exchange and transport to the skin for release. Redistribution of blood flow to these structures during heat stress also occurs in sheep (Hales, 1973). The present study showed an increase in heat flow to the tail compared with the shoulder and rump skin sites, in the absence of fans, during both AM and PM periods (Figure 4) to support the idea of increased blood flow to this region. It was unexpected that the skin temperature of the extremity skin sites would decrease, in the absence of fans, from $\mathrm{E}$ to $\mathrm{L}$ periods. However, if there was a reduction in metabolic heat production as reported for heat adaptation in cattle, then a reduction in extremity blood flow, expressed by a decrease in skin temperature, would have occurred.

Cows used in this study were wintered-adapted at the start of the study (February). We employed a Latin square design with $24 \mathrm{~d}$ between each trial. Cows returned to the university dairy between trials. The $24 \mathrm{~d}$ preceding trial 1 and the $24 \mathrm{~d}$ between trial 1 and 2 and between trials 2 and 3 were not the same with respect to ambient temperatures, humidity, or day length that the cows experienced. It would have been theoretically possible to keep all cows in the chambers for $24 \mathrm{~d}$ before the first trial and between trials 1 and 2 and 2 and 3 , but our experience is that cows benefit from rest periods between individual trials. In addition, it would have been in violation of our university Institutional Animal
Care and Use Committee requirement for chamber duration. These rest periods ensure that cows remain well exercised and healthy. Although cows may have slightly adapted to increasing environmental temperatures and day length during rest periods as the study progressed from February to May, the experimental design that we employed accounted for the effects of trial $(1,2$, or 3$)$ and removed this effect from the overall experimental error.

\section{CONCLUSIONS}

The benefit of fan cooling is highly dependent on the temperature of the air, with the amount of heat flow from the skin's surface being more than double with fan cooling at night when $T_{a}$ is typically less versus the day when in a low humidity environment. Night fan cooling is more effective than day fan cooling in maintaining daily milk yield in the heat, with the primary benefit being for the morning production. Night fan cooling maintains the minimum rectal and skin temperatures at the same level as for continuously cooled animals. However, maximum body temperatures were higher for night-cooled cows than for the other treatment groups. This suggests that minimum body temperature is more important than maximum in maintaining milk production in the heat. A continued reduction in milk production occurs with heat adaptation. However, this is only seen in day-cooled animals. In conclusion, minimum body temperature in cows, created with night cooling, is more important than maximum temperature in maintaining milk production during heat stress.

\section{ACKNOWLEDGMENTS}

Support was provided by the US Department of Agriculture-National Research Initiative Competitive Grants Program (USDA-NRI), "Strategic Cooling of Dairy Cows for Improved Summer Efficiency and Performance."

\section{REFERENCES}

Akari, C. T., R. M. Nakamura, and L. W. G. Kam. 1987. Diurnal temperature sensitivity of dairy cattle in a naturally cycling environment. J. Therm. Biol. 12:23-26.

Beakley, W. R., and J. D. Findlay. 1955. The effect of environmental temperature and humidity on the ear temperatures of Aryshire calves. J. Agric. Sci. 45:373-379.

Beede, D. K., and J. K. Shearer. 1991. Nutritional management of dairy cattle during hot weather. Agric. Practice 12:5-12.

Berman, A. 2005. Estimates of heat stress relief needs for Holstein dairy cows. J. Anim. Sci. 83:1377-1384.

Berman, A., Y. M. Folman, M. Kaim, Z. Mamen, D. Herz, A. Wolfenson, and Y. Graber. 1985. Upper critical temperatures and forced ventilation effects for high-yielding dairy cows in a tropical environment. J. Dairy Sci. 68:1488-1495. 
Berman, A., and M. Morag. 1971. Nychthemeral patterns of thermoregulation in high-yielding dairy cows in a hot dry near-natural climate. Aust. J. Agric. Res. 22:671-680.

Bitman, J., A. Lefcourt, D. L. Wood, and B. Stroud. 1984. Circadian and ultradian temperature rhythms of lactating dairy cows. J. Dairy Sci. 67:1014-1023.

Blazquez, N. B., S. E. Long, T. M. Mayhew, G. C. Perry, N. J. Prescott, and C. M. Wathes. 1994. Rate of discharge and morphology of sweat glands in the perineal, lumbodorsal and scrotal skin of cattle. Res. Vet. Sci. 57:277-284.

Bray, D. R., R. A. Bucklin, R. Montoya, and R. Gresig. 1994. Cooling methods for dairy housing in the southeastern United States. Trans. ASAE, Paper No. 94-4501. St. Joseph, MI.

Brown-Brandl, T. M., R. A. Eigenberg, G. L. Hahn, J. A. Nienaber, T. L. Mader, D. E. Spiers, and A. M. Parkhurst. 2005. Analysis of thermoregulatory responses of feeder cattle exposed to simulated heat waves. Int. J. Biometeorol. 49:285-296

Brown-Brandl, T. M., J. A. Nienaber, R. A. Eigenberg, G. L. Hahn, and H. Freetly. 2003. Thermoregulatory responses of feeder cattle. J. Therm. Biol. 28:149-157.

Collier, R. J., G. E. Dahl, and M. J. Van Baale. 2006. Major advances associated with environmental effects on dairy cattle. J. Dairy Sci. 89:1244-1253

Conover, W. J., and R. L. Iman. 1981. Rank transformations as a bridge between parametric and nonparametric statistics. Am. Stat. 35:124-129.

Correa-Calderon, A., D. Armstrong, D. Ray, S. DeNise, M. Enns, and C. Howison. 2004. Thermoregulatory responses of Holstein and Brown Swiss heat-stressed dairy cows to two different cooling systems. Int. J. Biometeorol. 48:142-148.

Cossins, A. R., and K. Bowler. 1987. Temperature Biology of Animals. Chapman and Hall, New York, NY.

Curtis, S. E. 1983. Environmental Management in Animal Agriculture. The Iowa State University Press, Ames.

de Andrade Ferrazza, R. A., H. D. M. Garcia, V. H. V. Aristizabal, C. S. Nogueira, C. J. Verissimo, J. R. Sartori, R. Sartori, and J. C. Pinheiro Ferreira. 2017. Thermoregulatory responses of Holstein cows exposed to experimentally induced heat stress. J. Therm. Biol. 66:68-80

Elvinger, F., R. P. Natzke, and P. J. Hansen. 1992. Interactions of heat stress and bovine somatotropin affecting physiology and immunology of lactating cows. J. Dairy Sci. 75:449-462.

Finch, V. A. 1985. Body temperature in beef cattle: Its control and relevance to production in the tropics. J. Anim. Sci. 62:531-542.

Gaughan, J. B., S. M. Holt, G. L. Hahn, T. L. Mader, and R. Eigenberg. 2000. Respiration rate: Is it a good measure of heat stress in cattle? Asian-australas. J. Anim. Sci. 13:329-332.

Gaughan, J. B., T. L. Mader, and S. M. Holt. 2008. Cooling and feeding strategies to reduce heat load of grain-fed beef cattle in intensive housing. Livest. Sci. 113:226-233.

Gebremedhin, K. G., C. N. Lee, P. E. Hillman, and R. J. Collier. 2010. Physiological responses of dairy cows during extended solar exposure. Trans. ASABE 53:239-247.

Gebremedhin, K. G., and B. Wu. 2001. A model of evaporative cooling of wet skin surface and fur layer. J. Therm. Biol. 26:537-545.

Giesbrecht, G. G., C. Jamieson, and F. Cahill. 2007. Cooling hyperthermic firefighters by immersing forearms and hands in $10 \mathrm{C}$ and 20C water. Aviat. Space Environ. Med. 78:561-567.

Hales, J. R. S. 1973. Effects of exposure to hot environments on the regional distribution of blood flow and on cardiorespiratory function in sheep. Pflugers Arch. 344:133-148.

Hansen, P. J. 1994. Causes and possible solutions to the problem of heat stress in reproductive management of dairy cows. Pages 161170 in Proceedings of the National Reproduction Symposium, ed. E.R. Jordan, Pittsburgh, PA.

Igono, M. O., G. Bjovedt, and H. T. Sanford-Crane. 1992. Environmental profile and critical temperature effects on milk production of Holstein cows in dessert climate. Int. J. Biometeorol. 36:77-87.

Ingram, D. L. 1964. The effect of environmental temperature on heat loss and thermal insulation in the young pig. Res. Vet. Sci. 5:357364 .
Ingram, D. L., and L. E. Mount. 1975. The cardiovascular system. Page 185 in Man and Animals in Hot Environments. SpringerVerlag, New York, NY.

Ingram, D. L., and G. C. Whittow. 1962. The effects of variations in respiratory activity and in the skin temperatures of the ears on the temperature of the blood in the external jugular vein of the ox (Bos taurus). J. Physiol. 163:211-221.

Ingram, D. L., and G. C. Whittow. 1963. Changes in arterial blood pressure and heart rate in the ox (Bos taurus) with changes of body temperature. J. Physiol. 168:736-746.

Kabuga, J. D. 1992. The influence of thermal conditions on rectal temperature, respiration rate and pulse rate of lactating Holstein-Friesian cows in the humid tropics. Int. J. Biometeorol. 36:146-150.

Kadzere, C. T., M. R. Murphy, N. Silanikove, and E. Maltz. 2002. Heat stress in lactating dairy cows: A review. Livest. Prod. Sci. 77:59-91.

Kendall, P. E., and J. R. Webster. 2009. Season and physiological status affects the circadian body temperature rhythm of dairy cows. Livest. Sci. 125:155-160.

Kibler, H. H. H. D. Johnson, M. D. Shanklin, and L. Hahn. 1965. Acclimation of Holstein cattle to 29C: Changes in heat producing and heat dissipating functions. MO Ag. Exp. Station Res. Bull. 893.

Kleiber, M. 1932. Body size and metabolism. Hilgardia 6:315-353.

Layton, R. P., W. H. Mints, J. F. Annis, M. J. Rack, and P. Webb. 1983. Calorimetry with heat flux transducers: Comparison with a suit calorimeter. J. Appl. Physiol. 54:1361-1367.

Maia, A. S. C., R. G. daSilva, and C. M. B. Loureiro. 2005. Sensible and latent heat loss from the body surface of Holstein cows in a tropical environment. Int. J. Biometeorol. 50:17-22.

Mallonee, P. G., D. K. Beede, R. J. Collier, and C. J. Wilcox. 1985. Production and physiological responses of dairy cows to varying dietary potassium during heat stress. J. Dairy Sci. 68:1479-1487.

McLean, J. A. 1963. The partition of insensible heat losses of body weight and heat from cattle under various climatic conditions. J. Physiol. 167:427-447.

Mendel, V. E., S. R. Morrison, T. E. Bond, and G. P. Lofgreen. 1971 Duration of heat exposure and performance in beef cattle. J. Anim. Sci. 33:850-854.

Mount, L. E. 1979. Adaptation to Thermal Environment. Man and His Productive Animals. Univ. Park Press, Baltimore, MD.

Mount, L. E., and D. L. Ingram. 1965. The effects of ambient temperature and air movement on localized sensible heat-loss from the pig. Res. Vet. Sci. 6:84-91.

Nadel, E. R., K. B. Pandolf, M. F. Roberts, and J. A. J. Stolwijk. 1974. Mechanisms of thermal acclimation to exercise and heat. J. Appl. Physiol. 37:515-520.

Nienaber, J. A., and G. L. Hahn. 2007. Livestock production system management responses to thermal challenges. Int. J. Biometeorol. $52: 149-157$.

Raman, E. R., M. F. Roberts, and V. J. Vanhuyse. 1983. Body temperature control of rat tail blood flow. Am. J. Physiol. 245:R426 R432.

Rhoads, M. L., R. P. Rhoads, M. J. VanBaale, R. J. Collier, S. R. Sanders, W. J. Weber, B. A. Crooker, and L. H. Baumgard. 2009. Effects of heat stress and plane of nutrition on lactating Holstein cows: I. Production, metabolism, and aspects of circulating somatotropin. J. Dairy Sci. 92:1986-1997.

Roberts, M. F., C. B. Wenger, J. A. J. Stolwijk, and E. R. Nadel. 1977 Skin blood flow and sweating changes following exercise and heat acclimation. J. Appl. Physiol. 43:133-137.

Roenfeldt, S. 1998. You can't afford to ignore heat stress. Dairy Management 35:6-12.

Romanovsky, A. A. 2014. Skin temperature: its role in thermoregulation. Acta Physiol. (Oxf.) 210:498-507.

Scharf, B., J. A. Carroll, D. G. Riley, C. C. Chase Jr., S. W. Coleman, D. H. Keisler, R. L. Weaber, and D. E. Spiers. 2010. Evaluation of physiological and blood serum differences in heat-tolerant (Romosinuano) and heat-susceptible (Angus) Bos taurus cattle during controlled heat challenge. J. Anim. Sci. 88:2321-2336.

Scott, I. M., H. D. Johnson, and G. L. Hahn. 1983. Effect of programmed diurnal temperature cycles on plasma thyroxine cycles, 
body temperature, and feed intake of Holstein dairy cows. Int. J. Biometeorol. 27:47-62.

Settivari, R. S., J. N. Spain, M. R. Ellersieck, J. C. Byatt, R. J. Collier, and D. E. Spiers. 2007. Relationship of thermal status to productivity in heat-stressed dairy cows given recombinant bovine somatotropin. J. Dairy Sci. 90:1265-1280.

Shearer, J. K., and D. K. Beede. 1990. Thermoregulation and physiological responses of dairy cattle in hot weather. Agric. Practice 11:5-11.

Silanikove, N. 2000. Effects of heat stress on the welfare of extensively managed domestic ruminants. Livest. Prod. Sci. 67:1-18.

Smith, J. F., and J. P. Harner III. 2012. Strategies to reduce the impact of heat and cold stress in dairy cattle facilities. Pages 267-288 in Environmental Physiology of Livestock. R. J. Collier and J. L. Collier, ed. John Wiley \& Sons, Hoboken, NJ.

Spiers, D. E., J. N. Spain, J. D. Sampson, and R. P. Rhoads. 2004. Use of physiological parameters to predict milk yield and feed intake in heat-stressed dairy cows. J. Therm. Biol. 29:759-764.

St-Pierre, N. R., B. Cobanov, and G. Schnitkey. 2003. Economic losses from heat stress by US livestock industries. J. Dairy Sci. 86:E52E77.

Steel. R. G. D., J. H. Torrie, and D. A. Dickey. 1997. Principles and Procedures of Statistics: A Biomedical Approach. McGraw-Hill, New York, NY.
Thom, E. C. 1959. The discomfort index. Weatherwise 12:57-59.

Turner, L. W., J. P. Chastain, R. W. Hemken, R. S. Gates. And, and W. L. Crist. 1992. Reducing heat stress in dairy cows through sprinkler and fan cooling. Appl. Eng. Agric. 8:251-256.

Wheelock, J. B., R. P. Rhoads, M. J. VanBaale, S. R. Sanders, and L. H. Baumgard. 2010. Effects of heat stress on energetic metabolism in lactating Holstein cows. J. Dairy Sci. 93:644-655.

Whittow, G. C. 1962. The significance of the extremities of the ox (Bos taurus) in thermoregulation. J. Agric. Sci. 58:109-120.

Wilson, S. J., R. S. Marion, J. N. Spain, D. E. Spiers, D. H. Keisler, and M. C. Lucy. 1998. Effects of controlled heat stress on ovarian function of dairy cattle. 1. Lactating cows. J. Dairy Sci. 81:21242131.

Wolfenson, D., B. J. Lew, W. W. Thatcher, Y. Graber, and R. Meidan. 1997. Seasonal and acute heat stress effects on steroid production by dominant follicles in cows. Anim. Reprod. Sci. 47:9-19.

Yamazaki, F., and K. Hamasaki. 2003. Heat acclimation increases skin vasodilation and sweating but not cardiac baroreflex responses in heat-stressed humans. J. Appl. Physiol. 95:1567-1574. 